\title{
Kajian Livable Street pada Jalur Pedestrian di Kawasan Pecinaan Lama Kota Bandung
}

\author{
Muhammad Adhitya R*, Weishaguna \\ Prodi Perencanaan Wilayah dan Kota, Fakultas Teknik, Universitas Islam \\ Bandung, Indonesia. \\ *adhitdoublezero@gmail.com, igun151175@yahoo.com
}

\begin{abstract}
This research on pedestrian in the old area of Bandung city of Bandung is aimed at overcoming the problem of the bad pedestrian path in the area of area of Bandung city of Bandung. The existence of the old city area of Bandung which is close to the new market can attract a lot of visitors' interest, unfortunately the condition of the existing pedestrian infrastructure in this area is inadequate. The number of street vendors who sell on pedestrian lanes, motorized parking on the sidewalks, uneven pedestrian lanes, to the lack of pedestrian facilities makes visitors less comfortable to move in this area. The concept of the theory that the authors apply to overcome the problem of pedestrian paths in this region is the concept of livable street. The author expects the theory of urban design and the concept of livable street as being able to overcome the problems regarding the pedestrian path in the old area of Bandung City. The method that I use is a qualitative approach by observing issues that exist and then assessing the criteria for the concept of livable street through the study of literature, then the process of analysis of pedestrian flows, the level of pedestrian services, pedestrian path width requirements, and analysis of variable variable from the concept of liveable street. This research was conducted to solve problems in pedestrian routes that are not liveable in the old Chinatown district of Bandung city.
\end{abstract}

Keywords: Pedestrian, Livable street, Old Chinese.

Abstrak. Penelitian tentang pedestrian di kawasan pecinaan lama Kota Bandung ini ditujukan untuk mengatasi permasalahan buruknya jalur pedestrian yang ada di kawasan pecinaan Kota Bandung. Keberadaan kawasan pecinaan lama Kota Bandung yang dekat dengan pasar baru dapat menarik banyak minat pengunjung, sayangnya kondisi infrastruktur pejalan kaki yang ada pada kawasan ini kurang memadai. Banyaknya pedagang kaki lima yang berjualan di atas jalur pedestrian, parkir kendaraan bermotor di atas trotoar, jalur pedestrian yang tidak rata, hingga minimnya fasilitas sarana pejalan kaki membuat pengunjung kurang nyaman untuk beraktivitas di kawasan ini. Konsep teori yang penulis terapkan untuk mengatasi permasalahan jalur pedestrian yang ada di kawasan ini adalah konsep livable street. Penulis mengharapkan teori perancangan kota dan konsep livable street sebagai dapat mengatasi permasalahan mengenai jalur pedestrian yang ada di kawasan pecinaan lama Kota Bandung. Metode yang penulis gunakan yaitu metode pendekatan kualitatif dengan mengamati isu-isu permasalahan yang ada kemudian mengkaji kriteria-kriteria konsep livable street melalui studi literatur, selanjutnya dilakukan proses analisis terhadap arus pejalan kaki, tingkat pelayanan pejalan kaki, kebutuhan lebar jalur pedestrian, dan analisis mengenai variabel variabel dari konsep liveable street. Penelitian ini dilakukan untuk memecahkan permasalahan pada jalur pedestrian yang tidak liveable di kawasan pecinaan lama kota bandung.

Kata Kunci: Pedestrian, Livable street, Pecinaan lama 


\section{A. Pendahuluan}

Keberadaan Pasar Baru sebagai pusat perdagangan menjadikan kawasan pasarbaru memiliki peran yang cukup penting bagi Kota Bandung. Kawasan Pasar Baru ini dibangun pada tahun 1896 untuk menampung pedagang yang membuka usahanya di sekitar Alun-alun dan Sumedangweg (Jl. Otista sekarang). Kawasan pasar baru Kota Bandung lebih dikenal sebagai kawasan Pecinaan lama. Kawasan pecinaan lama Kota Bandung ini merupakan sebuah kawasan pusat perdagangan atau komersil yang ramai dikunjungi orang untuk berbelanja segala kebutuhan rumah tangga. Keadaan ini membuat kawasan pecinaan lama dipenuhi pengunjung setiap harinya dari yang datang menggunakan moda transportasi publik maupun menggunakan kendaraan pribadi, pengunjung dari dalam Kota Bandung maupun dari luar kota bahkan dari luar negri, dan banyak mengundang para pedagang kaki lima untuk berjualan di trotoar yang berada di kawasan pecinaan lama Kota Bandung.

Jalur pedestrian merupakan ruang publik yang semestinya diciptakan untuk masyarakat dalam melakukan perjalanan dari tempat A ke tempat B dengan berjalan kaki. Akan tetapi jalur pedestrian yang diprioritaskan untuk para pejalan kaki tidak di indahkan oleh beberapa pihak untuk kepentingan pribadi. Kepentingan pribadi yang dimaksud dalam kasus ini berupa pedagang kaki lima yang berjualan atau mendirikan lapaknya diatas jalur pedestrian, ada pula masyarakat yang memarkirkan kendaraan bermotornya diatas jalur pedestrian, dan ada juga para pemilik toko yang masang barang display toko di atas jalur pedestrian. Selain permasalahan diatas, jalur pedestrian dalam wilayah studi ini juga kurang terawat dan seakan diabaikan oleh pemerintah Kota Bandung. Hal ini terlihat dengan banyaknya jalur pedestrian yang rusak dan berlubang, kurangnya penerangan pada malam hari, kurangnya vegetasi yang ditanam di sekitar wilayah studi sehingga kawasan tersebut terasa sangat panas dan gersang pada siang hari, dan minimnya fasilitas sarana jalur pedestrian/ruang pejalan kaki. Dengan adanya permasalahan ini akan menghambat kegiatan pergerakan orang maupun barang yang terjadi di kawasan pecinaan lama Kota Bandung.

\section{B. Landasan Teori}

Livable street memiliki beberapa prinsip dalam penerapannya, yaitu: menyediakan pilihan transportasi yang banyak, meningkatkan jumlah perumahan yang terjangkau, meningkatkan daya saing ekonomi, adanya dukungan dari masyarakat dalam menciptakan jalan yang livable, mengkoordinasikan dan meningkatkan kebijakan dan investasi, meningkatkan nilai kepedulian masyarakat terhadap lingkungan.

\section{Ruang Jalan Harus Aman dan Nyaman}

1. Lalu Lintas

Menentukan jenis jalan dengan kapasitas dan karakter jenis jalan untuk dimasukkan dalam skema adalah penting, pendekatan teknik ini didasarkan pada penentuan klasifikasi jalan. Jalan yang aman memiliki 2 fungsi yang aman (Appleyard, Donald, 1981) yaitu:

- Mengontrol kebiasaan dari traveller, beberapa karakteristik yang bisa mengontrol volume lalu lintas, komposisi, kecepatan dan kebiasaan adalah tikungan atau jalan yang lurus, blok yang panjang, lereng, lebar, penanda jalan, rambu-rambu, merubah trotoar, tanjakan jalan, zebra cross, garis jalan, landscape, dan beberapa aspek lainnya untuk membuat karakter jalan.

- Melindungi penduduk dan memberikan kompensasi, perubahan dari emisi lalu lintas (kebisingan, getaran dan polusi), bisa merubah karakteristik dari lingkungan di jalan. Beberapa faktor kritis yang paling mempengaruhi yaitu bertambahnya lereng jalan, bertambahnya kecepatan pada penurunan dari bukit, kebisingan, getaran, polusi udara.

\section{Pejalan Kaki}

Jalan tempat masyarakat beraktivitas dan tidak ada pengendara yang ugal-ugalan. Anak-anak harus bisa berjalan atau bermain sepeda dengan aman pada jalan lokal di sekolahnya, tempat berhenti bus sekolah, playground, dan parkir untuk para pengunjung. Pengendara mobil, mobil antar-jemput, dan kendaraan lainnya harus mengerti bahwa terdapat teritori di pedestrian. Ketika 
mengunjungi jalan ini dan oleh karena itu harus dengan pelan dan hati-hati.

1. Jalan yang livable memiliki lingkungan sehat.

Donal Appleyard 1981 mengatakan bahwa lingkungan jalan tidak boleh ribut atau ada getaran pada lalu lintas. Penduduk bisa tidur pada waktu siang dan malam dengan tenang. Kemudian mereka bisa menghirup udara segar dan tidak ada debu pada pintu dan jendelanya. Lingkungan jalan harus memiliki tempat dimana orang-orang bersosialisasi.

2. Ruang jalan sebagai ruang komunitas

Jalan harus memiliki tempat yang menjadi ruang komunal, dimana orang-orang bisa merasa senang kemudian mereka bisa bersosialisasi dengan mudah dan tidak terdapatnya orang asing. Jalan umum harus bisa menyaring keanehan yang terjadi pada kehidupan di kota, jalan bisa mendukung aktivitas penduduk, menjaga jalan tetap bersih (Appleyard, D 1981).

3. Jalan Memiliki Teritori yang Ramah

Jalan yang memiliki teritori yang ramah maksudnya adalah dimana penduduk saling melindungi ketika seseorang itu sedang tinggal sendiri, kemudian menjaga privasi orang lain, dimana penduduk itu merasa tidak sendiri dan penduduk itu mempunyai rasa tanggung jawab dan kebanggaan. Jika semua hal ini terjadi maka penduduk itu akan lebih menjaga daerah mereka sendiri, termasuk juga tanamannya, lalu mengawasinya dan penduduk saling menyapa (Appleyard, D. 1981).

4. Jalan yang unik sebagai jalan yang memiliki nilai sejarah

Orang-orang bangga karena memiliki identitas yang spesial pada tempatnya.Identitas yang unik bisa terlihat dari bagian rumah, sungai kecil dan pohon tua (Appleyard, Donald. 1981), oleh karena itu pentingnya place theory dalam spasial design yaitu pemahaman tentang culture dan karakteristik suatu daerah yang ada menjadi ciri khas untuk digunakan sebagai salah satu pertimbangan agar penghuni (masyarakat) tidak merasa asing di dalam lingkungannya.

\section{Ketentuan teknis Jalur pejalan kaki (trotoar)}

1. Lebar efektif lajur pejalan kaki berdasarkan kebutuhan satu orang adalah $60 \mathrm{~cm}$ dengan lebar ruang gerak tambahan $15 \mathrm{~cm}$ untuk bergerak tanpa membawa barang, sehingga kebutuhan total lajur untuk dua orang pejalan kaki bergandengan atau dua orang pejalan kaki berpapasan tanpa terjadi persinggungan sekurang-kurangnya $150 \mathrm{~cm}$.

2. Penghitungan lebar trotoar minimal menggunakan Persamaan :

$$
W=\frac{V}{35}+N
$$

Keterangan:

$\mathrm{W}$ : adalah lebar efektif minimum trotoar (m)

$\mathrm{V}$ : adalah volume pejalan kaki rencana/dua arah (orang/meter/menit)

$\mathrm{N}$ : adalah lebar tambahan sesuai dengan keadaan setempat (meter)

ditentukan dalam Tabel 1

Tabel 1. Nilai N

\begin{tabular}{ll}
\hline $\mathrm{N}($ meter) & Keadaan \\
\hline 1.5 & $\begin{array}{l}\text { Jalan di daerah dengan bangkitan pejalan kaki } \\
\text { tinggi } *\end{array}$ \\
\hline 1.0 & $\begin{array}{l}\text { Jalan di daerah dengan bangkitan pejalan kaki } \\
\text { sedang ** }\end{array}$ \\
\hline 0.5 & $\begin{array}{l}\text { Jalan di daerah dengan bangkitan pejalan kaki } \\
\text { renda*** }\end{array}$ \\
\hline
\end{tabular}

Keterangan:

* arus pejalan kaki > 33 orang/menit/meter, atau dapat berupa daerah pasar atau terminal

**arus pejalan kaki 16-33 orang/menit/meter, atau dapat berupa daerah perbelanjaan bukan pasar 
***arus pejalan kaki $<16$ orang/menit/meter, atau dapat berupa daerah lainnya

(Sumber : Pedoman perencanaan fasilitas pejalan kaki Kementrian Pekerjaan Umum dan Perumahan Rakyat No.02/SE/M/2018)

Berdasarkan Pedoman perencanaan fasilitas pejalan kaki Kementrian Pekerjaan Umum dan Perumahan Rakyat No.02/SE/M/2018, berikut adalah standar lebar trotoar sesuai dengan penggunaan lahannya.

Tabel 2. Standar Lebar Trotoar

Penggunaan Lahan di sekitarnya

Lebar minimum mutlak, c (m)

\begin{tabular}{lr}
\hline - perumahan & 1,20 \\
- sekolah & 1,50 \\
- pertokoan dan pusat-pusat & 2,00 \\
perbelanjaan & \\
- terminal dan pemberhentian & 1,50 \\
bis/angkot & \\
- pusat-pusat perkantoran & 1,50 \\
- pusat-pusat hiburan & 2,00 \\
- pusat-pusat kegiatan sosial & 1,50 \\
- daerah industri & 2,00 \\
- jembatan dan terowongan & 1,20
\end{tabular}

Sumber : Pedoman perencanaan fasilitas pejalan kaki Kementrian Pekerjaan Umum dan Perumahan Rakyat No.02/SE/M/2018

\section{Hasil Penelitian dan Pembahasan}

Berdasarkan perhitungan arus pejalan kaki, maka kita dapat melihat tingkat pelayanan pejalan kaki dengan menggunakan perhitungan berikut.

\section{Banceuy}

Kondisi jalan banceuy memiliki lebar trotoar 1,5m dengan volume pejalan kaki puncak dalam 15 menit yaitu $100 \mathrm{org} / 15 \mathrm{~min}$ pada pukul 12:45 - 13:00. Maka data tersebut dapat dimasukan dalam persamaan berikut untuk menentukan tingkat pelayanan pejalan kaki.

$$
\mathrm{Vp}=\frac{V 15}{15 \times W e} \rightarrow \frac{100}{15 \times 1,5}=4,4 \mathrm{ped} / \mathrm{min}
$$

Berdasarkan hasil perhitungan dan tabel 2.7 tentang tingkat pelayanan pejalan kaki pada ruas jalan Banceuy termasuk kedalam kategori LOS A.

\section{Pecinaan Lama}

Kondisi jalan Pecinaan lama memiliki lebar trotoar 1,5m dengan volume pejalan kaki puncak dalam 15 menit yaitu $192 \mathrm{org} / 15 \mathrm{~min}$ pada pukul 12:15 - 12:30. Maka data tersebut dapat dimasukan dalam persamaan berikut untuk menentukan tingkat pelayanan pejalan kaki.

$$
\mathrm{Vp}=\frac{V 15}{15 \times W e} \rightarrow \frac{192}{15 \times 1,5}=8,53 \mathrm{ped} / \mathrm{min}
$$

Berdasarkan hasil perhitungan dan tabel 2.7 tentang tingkat pelayanan pejalan kaki pada ruas jalan Pecinaan lama termasuk kedalam kategori LOS A. 


\section{Gang suniaraja}

Kondisi jalan Gang suniaraja memiliki lebar trotoar $1 \mathrm{~m}$ dengan volume pejalan kaki puncak dalam 15 menit yaitu $232 \mathrm{org} / 15 \mathrm{~min}$ pada pukul 12:30 - 12:45. Maka data tersebut dapat dimasukan dalam persamaan berikut untuk menentukan tingkat pelayanan pejalan kaki.

$$
\mathrm{Vp}=\frac{V 15}{15 \times W e} \rightarrow \frac{232}{15 \times 1}=15,5 \mathrm{ped} / \mathrm{min}
$$

Berdasarkan hasil perhitungan dan tabel 2.7 tentang tingkat pelayanan pejalan kaki pada ruas jalan Gang suniaraja termasuk kedalam kategori LOS A.

ABC

Kondisi jalan $\mathrm{ABC}$ memiliki lebar trotoar 1m dengan volume pejalan kaki puncak dalam 15 menit yaitu $144 \mathrm{org} / 15 \mathrm{~min}$ pada pukul 12:30 - 12:45. Maka data tersebut dapat dimasukan dalam persamaan berikut untuk menentukan tingkat pelayanan pejalan kaki.

$$
\mathrm{Vp}=\frac{V 15}{15 \times W e} \rightarrow \frac{144}{15 \times 1,5}=6,4 \mathrm{ped} / \mathrm{min}
$$

Berdasarkan hasil perhitungan dan tabel 2.7 tentang tingkat pelayanan pejalan kaki pada ruas jalan $\mathrm{ABC}$ termasuk kedalam kategori LOS A.

\section{Alkateri}

Kondisi jalan Alkateri memiliki lebar trotoar 1m dengan volume pejalan kaki puncak dalam 15 menit yaitu $65 \mathrm{org} / 15 \mathrm{~min}$ pada pukul 12:00 - 12:15 dan 12:45 - 13:00. Maka data tersebut dapat dimasukan dalam persamaan berikut untuk menentukan tingkat pelayanan pejalan kaki.

$$
\mathrm{Vp}=\frac{V 15}{15 \times W e} \rightarrow \frac{65}{15 \times 1,5}=2,8 \mathrm{ped} / \mathrm{min}
$$

Berdasarkan hasil perhitungan dan tabel 2.7 tentang tingkat pelayanan pejalan kaki pada ruas jalan Alkateri termasuk kedalam kategori LOS A.

\section{Kebutuhan lebar trotoar}

Berdasarkan hasil analisis tingkat pelayanan LOS pejalan kaki didapati ternyata tingkat pelayanan pejalan kaki di keseluruhan kawasan pecinaan lama Kota Bandung termasuk ke dalam kategori LOS A. Akan tetapi lebar trotoar yang ada di kawasan pecinaan Kota Bandung ini tidak memenuhi standar lebar trotoar yang telah ditetapkan oleh Kementrian Pekerjaan Umum dan Permukiman Rakyat dengan lebar minimal untuk kawasan pertokoan dan pusat perbelanjaan yaitu $2 \mathrm{~m}$. Berdasarkan fakta di lapangan tersebut, maka akan dilakukan perhitungan kebutuhan lebar trotoar di kawasan pecinaan Kota Bandung dengan persamaan berikut.

Keterangan :

$$
W=\frac{V}{35}+N
$$

W : Lebar efektif trotoar

$\mathrm{V}$ : Volume Maksimum pejalan kaki

$\mathrm{N}$ : 1 (Nilai koefisien pada Tabel 1, meskipun nilai 1 pada tabel tidak sesuai dengan persyaratan nilai arus pejalan kaki, tetapi kawasan pecinaan lama Kota bandung termasuk kedalam kawasan perbelanjaan sehingga tetap mendapat nilai koefisien 1).

1. Jalan Banceuy

$$
W=\frac{V}{35}+N \rightarrow \frac{7}{35}+1=1.2 m
$$

2. Jalan Pecinaan Lama

$$
W=\frac{V}{35}+N \rightarrow \frac{12}{35}+1=1.34 m
$$

3. Jalan Gang Suniaraja

$$
W=\frac{V}{35}+N \rightarrow \frac{8}{35}+1=1.22 m
$$


4. Jalan $\mathrm{ABC}$

$W=\frac{V}{35}+N \rightarrow \frac{15}{35}+1=1.42 m$

5. Jalan Alkateri

$W=\frac{V}{35}+N \rightarrow \frac{2}{35}+1=1.05 m$

\section{Kesimpulan}

\section{Ruang jalan yang aman dan nyaman}

1. Kebutuhan Lebar Trotoar

Setelah dilakukan penelitian maka di ketahui bahwa tingkat pelayanan pejalan kaki di kawasan pecinaan lama Kota Bandung tergolong pada kategori LOS A yang dimanabesar arus pejalan kaki $<16$ pedestrian/menit/meter. para pejalan kaki dapat berjalan dengan kecepatan yang relatif cepat. Berjalan cepat yang dimaksud adalah berjalan pada bahu jalan karena trotoar yang seharusnya digunakan oleh pejalan kaki telah dimanfaatkan oleh pedagang kaki lima dan parkir kendaraan bermotor. Meskipun di semua ruas jalan yang ada di kawasan pecinaan lama Kota Bandung termasuk kedalam Kriteria tingkat pelayanan pejalan kaki LOS A, akan tetapi lebar trotoar tidak sesuai dengan spesifikasi yang telah dibuat oleh Kementrian Pekerjaan Umum dan Perumahan Rakyat. Dari hasil perhitungan yang telah dilakukan dapat diketahui bahwa pelebaran lebar trotoar dikawasan pecinaan lama Kota Bandung masih kurang dari standar yang telah ditetapkan oleh Kementrian Pekerjaan Umum dan Perumahan Rakyat, yang dimana kawasan pecinaan lama Kota Bandung merupakan sebuah kawasan perdagangan/perbelanjaan yang harus memiliki lebar trotoar minimal $2 \mathrm{~m}$, Namun pada fakta di lapangan lebar maksimal trotoar di kawasan pecinaan lama Kota Bandung hanya 1,5m. Maka dari itu penulis menetapkan bahwa lebar trotoar yang ada di kawasan pecinaan lama Kota Bandung harus diperlebar sebesar 50cm sehingga memenuhi standar yang ada.

2. Pedagang Kaki lima

Keberadaan pedagang kaki lima di kawasan pecinaan lama Kota Bandung ini tersebar hampir ke seluruh kawasan. Berdasarkan data yang penulis peroleh dari survey dapat di ketahui jumlah pedagang kaki lima yang memiliki lapak menetap lebih sedikit dari pedagan kaki lima yang bergerak/dapat berpindah. Untuk mengatasi permasalahan pedagang kaki lima yang berjualan di atas trotoar dan di badan jalan, maka dilakukan relokasi pedagan kaki lima yang tersebar ke sebuah lokasi sehingga para pedagang kaki lima dapat terorganisir degnan baik dan tidak mengganggu pengguna trotoar.

3. Penerangan jalan

Berdasarkan dari identifikasi yang telah dilakukan dapat diketahui bahwa penerangan jalan pada Kawasan Pecinaan Lama tidak semua lampu berfungsi dengan baik, hal ini memberikan kesan yang tidak aman bagi pengguna jalan maupun pengguna jalur pedestrian terutama pada malam hari. Permasalahan ini dapat diselesaikan dengan memberikan perawatan yang baik dan rutin terhadap fasilitas penunjang jalur pejalan kaki. 


\section{Jalan livable memiliki lingkungan yang sehat}

1. Vegetasi

Berdasarkan dari hasil observasi terlihat bahwa kondisi vegetasi yang ada di kawasan pecinaan lama sangat kurang, hal ini akan berdampak pada penurunan kualitas udara di Kawasan pecinaan lama Kota Bandung yang selalu sibuk dengan lalu lintas kendaraan bermotor. Selain untuk memperbaiki kualitas udara yang ada di Kawasan Pecinaan Lama Kota Bandung, vegetasi juga berperan sebagai elemen peredam kebisingan sehingga masyarakat yang tinggal di ruko-ruko Pecinaan Lama Kota Bandung dapat tinggal lebih nyaman.

2. Ketersediaan tempat sampah

Keberadaan tempat sampah yang kurang dapat menyebabkan permasalahan permasalahan yang lebih parah seperti timbulnya penyakit menular yang ditimbulkan oleh bakteri dan virus yang terdapat pada sampah-sampah yang berserakan di jalan. Selain timbulnya penyakit menular, tumbunan sampah juga dapat menyumbat saluran air sehingga dapat menyebabkan banjir. Permasalahan ini dapat diselesaikan dengan memberikan tempat sampah di titik-titik yang memiliki konsentrasi pengunjung yang tinggi.

\section{Ruang jalan sebagai ruang komunitas}

Keterbatasan trotoar dan adanya PKL menjadi faktor utama kegiatan masyarakat yang menggunakan trotoar untuk beraktifitas menjadi terhambat. Fenomena ini terjadi pada daerah yang memiliki tingkat konsentrasi kegiatan yang tinggi dan sedang. Hambatan bagi kegiatan pengunjung ini dapat diatasi dengan pelebaran trotoar dan merelokasi pedagang kaki lima ke tempat yang strategis dan mudah diakses.

\section{Jalan memiliki teritori yang ramah}

Kawasan Pecinaan Lama Kota Bandung sudah memiliki sistem/manajemen keamanan yang baik yang berupa kegiatan siskamling yang diselenggarakan oleh masing masing blok secara bergiliran, selain itu ada juga blok yang memiliki sistem/manajemen keamanan tetap seperti mempekerjakan satpam dan memasang CCTV sehingga keamanan pada Kawasan Pecinaan Lama Kota Bandung ini sudah baik.

\section{Jalan unik yang memiliki nilai sejarah}

Bangsa tionghoa pertama kali datang ke Kota Bandung menetap di Kawasan Pecinaan Lama. Selain bangsa tionghoa, Kawasan Pecinaan Lama Kota bandung juga pada awalnya di huni oleh bangsa Arab dan India. Pada saat peristiwa Bandung Lautan Api, Kawasan Pecinaan Lama Kota bandung dibakar hangus sehingga orang-orang menetap di kawasan tersebut harus mengungsi ke daerah kosambi.

\section{Daftar Pustaka}

Anggraini,Niniek.2009.Pedestrian ways dalam perencanaan kota. Klaten: yayasan humaniora Appleyard, D. (1981). Livable Streets. University of California Press, Berkeley.

Ardhiansyah,Nicolaus Nino.2012. Peningkatan kualitas ruang jalan pada fungsi komersial kawasan candi borobudur. Jurnal arsitektur komposisi. Volume 10. Universitas Atma Jaya Yogyakarta.

Chiara, Joshep de. Koppelman, Lee E.1997.Standar perencanaan tapak. Penerjemah: ir. Januar Hakim. Jakarta : Penerbit Erlangga.

Sugiyono. 2014. Metode Penelitian Kuantitatif Kualitatif dan Research \& Development. Bandung : Alfabeta.

Synder,James C dan Catanese, Anthony J. 1979. Perencanaan kota. Jakarta : Erlangga

Warpani, Suwardjoko P.2002. pengelolaan lalulintas dan angkutan jalan. Bandung: Penerbit ITB.

Kunto, Haryoto.1985.Wajah Bandoeng Tempo Doeloe.Bandung : PT.Granesia 
Yulintania, Vinca. 2013. Penataan Ruang Jalan Di Kawasan Ampel Dengan Konsep Livable Street (Studi Kasus : Koridor Jalan Nyamplungan Dan Pegirian, Surabaya). Tesis. Yogyakarta. Universitas Gadjah Mada.

Peraturan Daerah Kota Bandung Nomor : 10 Tahun 2015 Tentang Rencana Detail Tata Ruang Dan Peraturan Zonasi Kota Bandung Tahun 2015 - 2035.

Keputusan Mentri Perhubungan Nomor Km.65/1993 Tentang Fasilitas Pendukung Kegiatan Lalu Lintas Dan Angkutan Jalan.

Rencana Tata Ruang Wilayah Kota Bandung Tahun 2011-2031 